\title{
Reducing avian mortality from noise barrier collisions along an urban roadway
}

\author{
Cezary Mitrus $^{1} \cdot$ Adam Zbyryt $^{2}$
}

Published online: 27 November 2017

(C) The Author(s) 2017. This article is an open access publication

\begin{abstract}
Anthropogenic changes, including road network, have strongly influenced biodiversity of Europe. For the past 100 years road networks have become a conspicuous part of European landscape and strongly affected environment and human well-being, including effect by noise. To reduce impact of noise the special barriers (mainly transparent) are installed along a road. Annually thousands of birds die in collision with glass and acrylic screens, and these are important causes of avian mortality. Here we report about and describe how to prevent the lethal hazards that clear and acrylic (plastic) noise barriers along an urban road in eastern Poland pose to birds. A total of 114 fatal strikes representing 26 species were documented along transparent noise barriers. In unmodified sections in both study periods (2012/2013 and 2013/2014) we observed differences in number of fatalities between the seasons, the dead birds were found mostly in the summer, less in the spring and autumn and fewest in winter, but no differences were found between study periods (2012/2013 v. 2013/2014). These result we treat as base line or control data and compare them to experimental modification of the same barriers. After applying a film consisting of horizontal black thick stripes the number of fatal strikes decreased significantly. The average number of fatalities decreased from 1.02 to 0.06 ind. $/ \mathrm{km}$ for all panels of all sections combined and the number of species killed decreased from 19 in unmodified to 4 in modified sections. We highly recommend this effective and inexpensive application as a responsible public utility measure to protect bird life found near roads.
\end{abstract}

Keywords Birds $\cdot$ Collisions $\cdot$ Roads $\cdot$ Noise barriers

\section{Introduction}

The first roads were constructed in Europe more than 2000 years ago (Ritters and Wickham 2003). Within the last 100 years, modern construction has paved and made roads wider and straighter with little attention or concern for vegetation structure and animals, topography, and soil (Ritters and Wickham 2003). Transportation networks have increased with regional economic growth (Taaffe and Gauthier 1973; Haggett 1965). Road construction has economic, environmental, social and political impacts in urban and rural settings (Forman and Alexander 1998; Forman et al. 2003; Seiler 2001). Environmental disturbances include chemical and noise pollution, habitat fragmentation, and direct and indirect wildlife mortality (Erritzoe et al.

Cezary Mitrus

mitrus@univ.rzeszow.pl

1 Department of Zoology, University of Rzeszów, Zelwerowicza 4, 35-601 Rzeszów, Poland

2 The Polish Society for Birds Protection (PTOP), Ciepła 17, 15-471 Białystok, Poland
2003; Erickson et al. 2005; Coffin 2007; Loss et al. 2014; Morelli et al. 2015). Birds living near roads are especially vulnerable. Although some bird species also benefit from roadways (Morelli et al. 2014), however in most cases effects from roadways are detrimental to birds. They are directly injured or killed outright from collisions with vehicles or noise barriers, or indirectly harmed from habitat contamination, fragmentation, and loss (Kaseloo and Tyson 2004; Reijnen and Foppen 2006; Kociolek et al. 2011; Campedelli et al. 2014).

Transparent barriers constructed along roadways to reduce or block traffic noise can be especially lethal to birds (Coffin 2007; Loss et al. 2014; Morelli et al. 2014; Rössler et al. 2015), and several studies have investigated how to prevent collisions between birds and clear and reflective panes (Klem 2006, 2009). The use of marks with various patterns visible to birds and humans are known to be an effective collision prevention method (Rössler et al. 2007, 2009, 2015; Schmid et al. 2013). The various methods are used to reduce bird collisions with acoustic panels, however the birds mortality is still an actual problem (Zbyryt et al. 2012; Campedelli et al. 2014; Rössler et al. 2015) which required new studies and solutions. 
In this paper we describe how simple and inexpensive modification to transparent noise barriers can be used to prevent fatal bird strikes. The modification we found effective can serve as a model to guide transportation engineers in making existing and new roads and their noise barriers safe for birds.

\section{Study area}

Białystok $\left(53^{\circ} 07^{\prime} \mathrm{N} 23^{\circ} 10^{\prime} \mathrm{E}, 102 \mathrm{~km}^{2}\right)$ is the largest city in NE Poland. Population density is 2.9 people per $\mathrm{km}^{2}$. The city has a continental climate, characterized by warm temperatures during summer, long cold winters. This region is one of the coldest in Poland with average temperatures of $-4.3{ }^{\circ} \mathrm{C}$ in January and $6.8{ }^{\circ} \mathrm{C}$ annually. Mean annual rainfall oscillate around $590 \mathrm{~mm}$ and vegetative growing period lasts 200 to 210 day (Górniak 2000). Forests an important part of Białystok and occupy around 1750 ha (17\% of city landscape). There are two nature reserves: Zwierzyniecki Woods (mostly decidues forest dominated by Hornbeam Carpinus betulus) and Antoniuk (mixed forest dominated by Scots pine Pinus sylvestris, Spruce Picea abies and Hazel Corylus avellana). The reserve vegetation is relatively undisturbed and consists of flora typically found in more isolated forest communities. Some 100 year-old hornbeams and alders occur in the reserve Zwierzyniecki Woods. In 2009 a new road (Saint Father Pio Street) was built with noise barriers along part of Zwierzyniecki Woods and nearly houses. The average traffic volume in 2010-2014 was 654 vehicles/h (Gierasimiuk and Motylewicz 2014). In vicinity of study area were no breeding Magpies Pica pica and other Corvids (Zbyryt and Banach 2014) nor traits of Martens Marten sp. and Foxes Vulpes vulpes (Zbyryt et al. 2012) - scavengers which can significantly reduce the number of collision victims found (Klem 1990a).

\section{Material and methods}

We conducted our study from May 2012 to April 2014 along a city street with three sections of acrylic noise barriers $(\mathrm{A}=$ $160 \mathrm{~m}, \mathrm{~B}=500 \mathrm{~m}$ and $\mathrm{C}=550 \mathrm{~m}$ ). The barriers were $6 \mathrm{~m}$ high with the lower portion made of concrete $(2 \mathrm{~m})$ and the upper part consisting of clear acrylic. They were installed 9.5$13.5 \mathrm{~m}$ from the road edge. Section A was installed to cover Zwierzyniecki Woods; sections $\mathrm{B}$ and $\mathrm{C}$ were installed to protect housing, and section $\mathrm{C}$ also covered a forest patch. In 2010 silhouettes of birds of prey (goshawk shape and size) were placed on all noise barriers. Sections A and B were monitored on both sides, but Section $\mathrm{C}$ only along the street side because there was no access on the other private property sides. All sections were checked for carcasses ( $N=137$ controls) on foot by one of seven experienced ornithologists in the morning (usually between 7 and 9 am), from May to August every 3-4 days; in other months once per week. Justifying the search period interval, an earlier experiment on the timing of specimen removal documented $17 \%$ of strike casualties were removed during the first week and the most collisions were recorded in summer - almost 25 -fold more than in winter (Zbyryt et al. 2012). The length of a complete run along the monitored barriers was $1870 \mathrm{~m}$. A single field visit took from 1 (autumn/winter) to $1.5 \mathrm{~h}$ (spring/summer). The location and species were recorded for each collision event. Collision specimens were identify to the species and removed to avoid counting the same bird twice. The specimens were deposited in the Nature Museum of the University of Bialystok. All observers used the same checking method over all barriers to standardize monitoring. At the beginning of May 2013, a glossy black adhesive film consisting of a new pattern of horizontal stripes ( $2 \mathrm{~mm}$ thick separated by $28 \mathrm{~mm}$, commercially identified as 2;8 h// 2 schwarz Folie/Glas, see Schmid et al. 2013) was applied and covered the entire surface of Section A (Fig. 1). We did not monitor breeding bird density along each section for their respective study periods, but during this time no changes in structure of habitat, vegetation composition in the immediate vicinity were recorded. It also suggests no significant changes in species composition and relative density of birds along the entire study period and site.

To compare number of birds and species before and after modification the chi- square test with Yates's corrections was used. Because no differences between number of individuals and birds species along section B and C was observed (Zbyryt et al. 2012) data from these sections were pooled.

\section{Results}

A total of 114 fatal strikes representing 26 species were recorded during the first year of study. The most often noticed species were Hawfinch Coccothraustes coccothraustes, Black bird Turdus merula and Bohemian waxwing Bombycilla garrulus (Table 1). In unmodified sections in both study periods (2012/2013 and 2013/2014) we observed differences in number of fatalities between the seasons, the dead birds were found mostly in the summer (June - August, 57.9\% and $57.1 \%$ ), next in the spring (March - May, $22.8 \%$ and $17.2 \%$ ) and in autumn (September - November, $14.9 \%$ and $20.0 \%$ ), fewest in winter (December - February, $3.4 \%$ and $5.7 \%$ ), but no differences were found between study periods $\left(2012 / 2013\right.$ v. $\left.2013 / 2014, \chi^{2}=1.67 ; \mathrm{df}=3 ; p=0.64\right)$. After applying the black stripes to the clear barriers bird mortality 


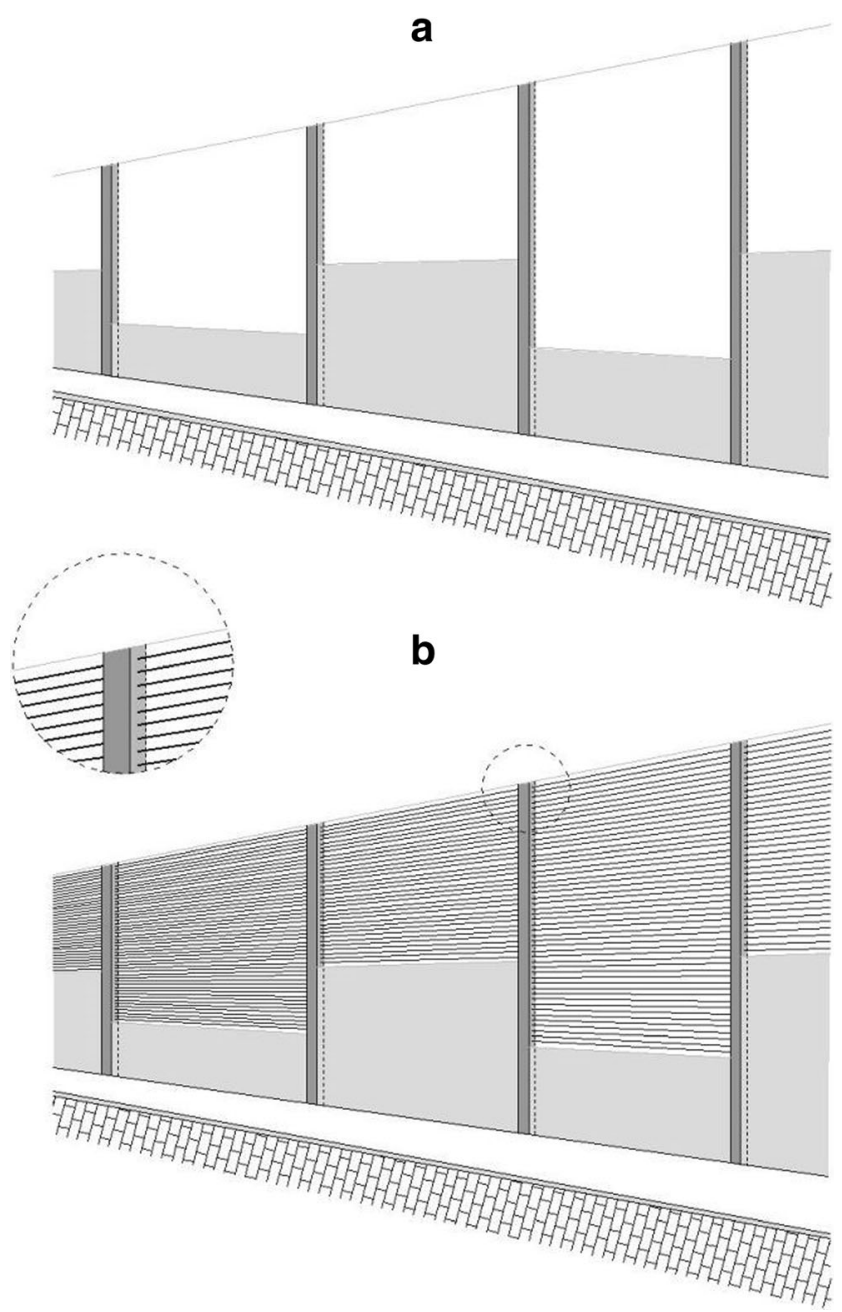

Fig. 1 Noise barriers before (top) and after (bottom) the application of black striped pattern to prevent bird strikes

decreased more than 15 times. Mortality differed significantly between two groups of panels before and after modifications $\left(\chi^{2}\right.$ with Yates's correction $\left.=27.45 ; \mathrm{df}=1 ; p<0.001\right)$, and the average number of fatalities decreased from 1.02 to 0.06 ind./ $\mathrm{km}$ for one control of all panels of all sections combined (Table 1). The number of different species killed decreased from 19 to 4 in section A; but was unchanged in sections B and $\mathrm{C}$ without the black stripes ( $\chi^{2}$ with Yates's correction $=$ $6.49 ; \mathrm{df}=1 ; p=0.03$; Table 2).

\section{Discussion}

Humans have likely always changed the environment in which they live and certainly from the time of the first cities about 4500 BCE. Dwellings, open space, and roadways in urban areas have offered benefits and hazards to co-habiting wildlife, especially birds (Calvert et al. 2013). Environmental hazards for birds include habitat fragmentation, noise, predation by cats and collisions with vehicles and other human-built structures (Klem 1990a; Mumme et al. 2000; Lepczyk et al. 2003; Borden et al. 2010; Balogh et al. 2011; Blancher 2013; Bishop and Brogan 2013; Hager et al. 2013; Machtans et al. 2013; Loss et al. 2014). Birds collide with stationary and moving vehicles, wind turbines, communication towers, power lines, fences, and windows in all types of human structures, to include noise barriers along roadways (Klem 1989, 1990a, 2009; Drewitt and Langston 2008). With the exception of complete habitat destruction, sheet glass in the form of clear and reflective windows may kill more birds than any other human-associated avian mortality factor (Klem 2006; Erickson et al. 2005; Zbyryt et al. 2012). A number of studies have described how birds behave as if clear and transparent windows are invisible to them, flying into clear panes attempting to reach habitat seen behind the glass, and into panes reflecting the facing habitat and sky (Klem 1989, 2009). Lateral eye placement may impair recognizing and avoiding glass barriers, but the deceptive features of clear and reflective panes likely best explain most bird-window collisions (Martin 2007, 2009). Our results of this study confirmed that transparency of noise barriers are dangerous for birds and the use of bird silhouettes appeared to be ineffective. We observed significant differences in numbers of dead birds between the seasons. The highest mortality was noticed in summer and spring, it indicates that victims were mainly local birds breeding and foraging in vicinity of barriers.

Various solutions are available to reduce bird collisions with human-made structures. Those that effectively reduce the probability of collisions consist of markings that birds can detect and avoid. Preventing bird strikes at power lines has been effective by attaching coils and flagging (Bevanger 1994; Janss and Ferrer 1998), at fences by using flags (Summers and Dugan 2001), but even with these attachments strikes still occur in large numbers at some power lines (Janss and Ferrer 2000; Drewitt and Langston 2008). Several solutions exist to uniformly cover a window where the covering pattern elements are separated by $10 \mathrm{~cm}$ oriented in vertical columns and $5 \mathrm{~cm}$ oriented in horizontal rows to transform sheet glass and acrylic panes into barriers that birds will see and avoid (Klem 1989, 1990b, 2009 but see also Capitani et al. 2007). The use of ultraviolet (UV) signals that birds see and humans do not have proven to be effective (Klem and Saenger 2013), but no noise barriers using this technology are currently available for sale; additionally, UV patterns are likely to be less effective for some species than others given the diversity of perception in the avian visual system (Håstad and Ödeen 2014). The use of single silhouettes in the form of birds of prey are popular but ineffective, as our results and those of others have found (Klem 1989, 1990b; Trybus 2003). Thus markings should be chosen according to birds ability to trigger an evasion response. The nets, screens or grilles placed 
Table 1 Birds species colliding with noise barriers along an urban roadway in Białystok
Before experiment (2012/2013)
After experiment (2013/2014)

Species

Section B + C (control) Section A (without stripes) Total Section B + C (control) Section A (with stripes) Total

Coccothraustes coccothraustes

Turdus merula

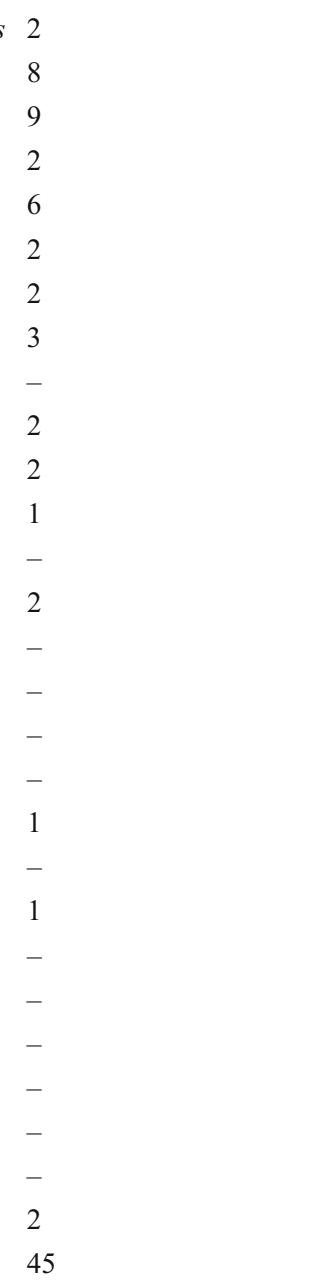

\begin{tabular}{|c|c|c|c|c|}
\hline 23 & 25 & 3 & 1 & 4 \\
\hline 5 & 13 & 7 & - & 7 \\
\hline 1 & 10 & - & - & - \\
\hline 7 & 9 & 1 & - & 1 \\
\hline 3 & 9 & 2 & - & 2 \\
\hline 5 & 7 & 4 & - & 4 \\
\hline 4 & 6 & 5 & 1 & 6 \\
\hline 2 & 5 & 2 & - & 2 \\
\hline 5 & 5 & - & - & - \\
\hline 1 & 3 & - & - & - \\
\hline- & 2 & - & - & - \\
\hline 1 & 2 & 1 & - & 1 \\
\hline 2 & 2 & - & - & - \\
\hline- & 2 & - & - & - \\
\hline 2 & 2 & - & 1 & 1 \\
\hline 1 & 1 & - & - & - \\
\hline 1 & 1 & - & - & - \\
\hline 1 & 1 & - & - & - \\
\hline - & 1 & - & - & - \\
\hline 1 & 1 & & - & - \\
\hline- & 1 & 1 & - & 1 \\
\hline 1 & 1 & 1 & - & 1 \\
\hline- & - & 1 & - & 1 \\
\hline- & - & - & 1 & 1 \\
\hline- & - & 1 & - & 1 \\
\hline - & - & 3 & - & 3 \\
\hline- & - & 1 & - & 1 \\
\hline 3 & 5 & 2 & - & 2 \\
\hline 69 & 114 & 35 & 4 & 39 \\
\hline
\end{tabular}

at a safe distance in front of windows or other densely spaced, visible markings on the glass are more effective solutions to prevent avian window collisions. This study confirms results obtained earlier under experimental conditions (Rössler et al., 2015) and indicate that simple line patterns are effective in mitigating bird-barrier collisions. In addition, what is worth emphasizing, this is a relatively inexpensive method (ca $10 €$ per square meter in this case) and due to its small coverage of pattern $(6.7 \%)$ is more public acceptable then others solutions.

Table 2 Avian mortality (the number of species, mean and standard error (SE) of the number of bird deaths per one visit) at clear noise barriers along an urban roadway in eastern Poland before and after application of a black striped pattern to prevent bird collisions (respectively 68 and 69 controls per year)

\begin{tabular}{lllrr}
\hline Type of barrier & Year & No of species & No of killed birds & Mean \\
\hline Modified & $2012 / 13$ (before) & 19 & 69 & 1.015 \\
& $2013 / 14$ (after) & 4 & 4 & 0.058 \\
Unmodified & $2012 / 13$ (before) & 15 & 45 & 0.116 \\
& $2013 / 14$ (after) & 15 & 35 & 0.662 \\
\end{tabular}




\section{Conclusions}

Our findings supported that a black line pattern, as a simply, inexpensive modification effectively reduce bird collisions with clear acrylic noise barriers along roadways. We highly recommend this effective application as a responsible public utility measure to protect birds.

Acknowledgements This research did not receive any specific grant from funding agencies in the public, commercial, or not-for-profit sectors. We thank Rafał Siuchno, Wojciech Raczkowski, Monika Zachorowska and Krzysztof Olechno and Justyna Połocka for help in the field, Piotr Tryjanowski and Daniel Klem Jr. for their comments which helped to improve the manuscript, Wiktor Żmieńka for help with drawing figure.

Open Access This article is distributed under the terms of the Creative Commons Attribution 4.0 International License (http:// creativecommons.org/licenses/by/4.0/), which permits unrestricted use, distribution, and reproduction in any medium, provided you give appropriate credit to the original author(s) and the source, provide a link to the Creative Commons license, and indicate if changes were made.

\section{References}

Balogh AL, Ryder TB, Marra PP (2011) Population demography of gray catbirds in the suburban matrix: sources, sinks and domestic cats. J Ornithol 152(3):717-726. https://doi.org/10. 1007/s10336-011-0648-7

Bevanger K (1994) Bird interactions with utility structures; collision and electrocution, causes and mitigating measures. Ibis 136:412-425. https://doi.org/10.1111/j.1474-919X.1994.tb01116.x

Bishop CA, Brogan JM (2013) Estimates of avian mortality attributed to vehicle collisions in Canada. Avian Conserv Ecol 8(2). https://doi.org/10.5751/ACE-00604-080202

Blancher P (2013) Estimated number of birds killed by house cats (Felis catus) in Canada. Avian Conserv Ecol 8(2):3. https://doi.org/10. 5751/ACE-00557-080203

Borden WC, Lockhart OM, Jones AW, Lyons MS (2010) Seasonal, taxonomic, and local habitat components of bird-window collisions on an urban university campus in Cleveland, $\mathrm{OH}$. Ohio J Sci 110:44-52 http://hdl.handle.net/1811/52787

Calvert AM, Bishop CA, Elliot RD, Krebs EA, Kydd TM, Machtans CS, Robertson GJ (2013) A synthesis of human-related avian mortality in Canada. Avian Conserv Ecol 8(2):11. https://doi.org/10.5751/ ACE-00581-080211

Campedelli T, Londi G, Cutini S, Donati C, Florenzano GT (2014) Impact of noise barriers on birds. A case study along a Tuscany highway. Avocetta 38:37-39

Capitani F, Dinetti M, Fangarezzi C, Piani C, Selmi E (2007) Barriere fonoassorbenti trasparenti: impatto sull'avifauna nel la periferia della città di Modena. Riv Ital Orn 76(2):115124. https://doi.org/10.5751/ACE-00557-080203

Coffin AW (2007) From roadkill to road ecology: a review of the ecological effects of roads. J Transp Geogr 15(5):396-406. https://doi.org/10.1016/j.jtrangeo.2006.11.006

Drewitt AL, Langston RHW (2008) Collision effects of wind-power generators and their obstacles on birds. Ann N Y Acad Sci 1134(1):233266. https://doi.org/10.1196/annals. 1439.015

Erickson WP, Johnson GD, Young DP Jr (2005) A summary and comparison of bird mortality from anthropogenic causes with an emphasis on collisions. General technical report PSW-GTR-191. U.S. Department of Agriculture, Washington DC

Erritzoe J, Mazgajski TD, Rejt $\_$(2003) Bird casualties on European roads - a review. Acta Ornithol 38(2):77-93. https://doi.org/10.3161/068.038.0204

Forman RTT, Alexander AE (1998) Roads and their major ecological effects. Annu Rev Ecol Syst 29(1):207-231. https://doi.org/10. 1146/annurev.ecolsys.29.1.207

Forman RTT, Sperling D, Bissonette JA, Clevenger AP, Cutshall CD, Dale VH, Fahrig L, France RL, Goldman CR, Heanue K, Jones J, Swanson F, Turrentine T, Winter TC (2003) Road ecology: science and solutions. Island Press, Washington, D.C.

Gierasimiuk P, Motylewicz M (2014) The noise in precincts of roads and streets - evaluation problems and preservation activity. In: Skoczko I, Piekutin J, Zarzecka A (eds) Environment engineering - young eye, sanitary and engineering conditioning. VII OWPB Białystok, pp 59-93 (in Polish)

Górniak A (2000) Climate of Podlaskie province. IMGiW, Białystok (in Polish)

Hager SB, Cosentino BJ, McKay KJ, Monson C, Zuurdeeg W, Belvins B (2013) Window area and development drive spatial variation in birdwindow collisions in an urban landscape. PLoS One 8(1):e53371. https://doi.org/10.1371/journal.pone.0053371

Haggett P (1965) Locational analysis in human geography. Edward Arnold, London

Håstad O, Ödeen A (2014) A vision physiological estimation of ultraviolet window marking visibility to birds. Peer J 2:e621. https://doi.org/10.7717/peerj.621

Janss GFE, Ferrer M (1998) Rate of birds collision with power lines: effect of conductor marking and static wire-marking. J Field Ornithol 69:8-17

Janss GFE, Ferrer M (2000) Common crane and great bustard collision with power lines: collision rate and risk exposure. Wildl Soc Bull 28: 675-680

Kaseloo PA, Tyson KO (2004) Synthesis of noise effects on wildlife populations. FHWA Report

Klem D Jr (1989) Bird-window collisions. Wilson Bull 101:606-620

Klem D Jr (1990a) Bird injuries, cause of death, and recuperation from collisions with windows. J Field Ornithol 61:115-119

Klem D Jr (1990b) Collisions between birds and windows: mortality and prevention. J Field Ornithol 61:120-128

Klem D Jr (2006) Glass: a deadly conservation issue for birds. Bird Observer 34:73-81

Klem D Jr (2009) Avian mortality at windows: the second largest human source of bird mortality on earth. Proceedings of the fourth International Partners in Flight Conference: tundra to tropic pp 244-251

Klem D Jr, Saenger PG (2013) Evaluating the effectiveness of select visual signals to prevent bird-window collisions. Wilson J Ornithol 125(2):406-411. https://doi.org/10.1676/12-106.1

Kociolek AV, Clevenger AP, St Clair CC, Proppe DS (2011) Effects of road networks on bird populations. Conserv Biol 25(2):241-249. https://doi.org/10.1111/j.1523-1739.2010.01635.x.

Lepczyk CA, Mertig AG, Liu J (2003) Landowners and cat predation across rural-to-urban landscapes. Biol Conserv 115(2):191-201. https://doi.org/10.1016/S0006-3207(03)00107-1

Loss SR, Will T, Loss SS, Marra P (2014) Bird-building collisions in the United States: estimates of annual mortality and species vulnerability. Condor 116(1):8-23. https://doi.org/10.1650/CONDOR-13-090.1

Machtans CS, Wedeles CHR, Bayne EM (2013) A first estimate for Canada of the number of birds killed by colliding with building windows. Avian Conserv Ecol 8(2):6. https://doi.org/10.5751/ ACE-00568-080206

Martin GR (2007) Visual fields and their functions in birds. J Ornithol 148(1636):547-562. https://doi.org/10.1098/rstb.2013.0040

Martin GR (2009) What is binocular vision for? A birds' eye view. J Vis 9(11):1-19. https://doi.org/10.1167/9.11.14 
Morelli F, Beim M, Jerzak L, Jones D, Tryjanowski P (2014) Can roads, railways and related structures have positive effects on birds? A review. Transp Res Part D 30:21-31. https://doi.org/10.1016/j.trd. 2014.05.006

Morelli F, Jerzak L, Pruscini F, Santolini R, Benedetti Y, Tryjanowski P (2015) Testing bird response to roads on a rural environment: a case study from Central Italy. Acta Oecol 69:146-152. https://doi.org/10. 1016/j.actao.2015.10.006

Mumme RI, Schoech SJ, Woolfenden GE, Fitzpatrick JW (2000) Life and death in the fast lane: demographic consequences of road mortality in the Florida Scrub-jay. Conserv Biol 14(2):501-512. https://doi.org/10.1046/j.1523-1739.2000.98370.x

Reijnen R, Foppen R (2006) Chapter 12: impact of road traffic on breeding bird populations. In: Davenport J, Davenport JL (eds) The ecology of transportation: managing mobility for the environment. Springer, The Netherlands, pp 255-274. https://doi.org/10.1007/14020-4504-2_12

Ritters KH, Wickham JD (2003) How far to the nearest road? Front Ecol Environ 1(3):125-129. https://doi.org/10.1890/1540-9295(2003) 001[0125:HFTTNR]2.0.CO;2

Rössler M, Laube W, Weihs P (2007) Vermeidung von Vogelanprall an lasflächen. Experimentelle Untersuchungen zur Wirksamkeit von lasmarkierungen unter natürlichen Lichtbedingungen im Flugtunnel II, Bilogische Station Hohenau-Ringelsdorf (In German)
Rössler M, Laube W, Weihs P (2009) Avoiding bird collisions with glass surfaces. Experimental investigations of the efficacy of markings on glass panes under natural light conditions in Flight Tunnel II Final report (March 2007)

Rössler M, Nemeth E, Bruckner A (2015) Glass pane markings to prevent bird-window collisions: less can be more. Biologia 70(4):535-541. https://doi.org/10.1515/biolog-2015-0057

Schmid H, Doppler W, Heynen D, Rössler M (2013) Bird-friendly building with glass and light. Swiss Ornithological Institute Sempach

Seiler A (2001) Ecological effects of roads, a review. Introductory research essay no 9 department of conservation biology swedish university of agricultural science Upsalla

Summers RW, Dugan D (2001) An assessment of methods used to mark fences to reduce bird collisions in pinewoods. Scott For 55:23-29

Taaffe EJ, Gauthier HL (1973) Geography of transportation. PrenticeHall Inc, Englewood Cliffs

Trybus T (2003) Wirksamkeit von Greifvogelsilhouetten zur Verhinderung von Kleinvogelanprall an Glas-fronten. Die These des Masters der Universität Wien (in German)

Zbyryt A, Banach J (2014) Numbers, density and characteristics of nesting sites of the Magpie Pica pica in Białystok (NE Poland) Ornis Polonica 55:105-114 (in Polish with English abstract)

Zbyryt A, Suchowolec A, Siuchno R (2012) Species composition of birds colliding with noise barriers in Białystok (north-eastern Poland). Int Stud Sprrows 36:88-94 